\title{
The assemblages of aquatic Coleoptera from shallow lakes in the northern Iberian Meseta: Influence of environmental variables
}

\author{
LuIS F. VALLADARES ${ }^{1}$, JosEFina GARRIDO² and FRANCISCO GARCÍA-CRIADO ${ }^{1}$ \\ ${ }^{1}$ Departamento de Biología Animal, Facultad de Ciencias Biológicas y Ambientales, Universidad de León, 24071 León, Spain; \\ e-mail: dbalvd@unileon.es \\ ${ }^{2}$ Departamento de Ecología y Biología Animal, Facultad de Ciencias, Universidad de Vigo, 36200 Vigo, Spain; e-mail: \\ jgarrido@uvigo.es
}

Key words. Assemblages of Coleoptera, shallow lakes, environmental variables, Iberian Peninsula, multivariate analysis.

\begin{abstract}
Aquatic Coleoptera in shallow lakes associated with the Canal de Castilla (Palencia Province, Spain) in the northern Iberian Meseta were sampled over the course of a year (spring 1998-winter 1999). These waterbodies are typical plateau wetlands with dense vegetation and vary in permanence and area (from 3.3 ha to 29.35 ha). Oxygen concentration, conductivity and $\mathrm{pH}$ were recorded at the time of sampling. Lake area, depth, water permanence and type of vegetation were also taken into account. Ninety two species were collected. Species richness was high in comparison with other wetlands in Spain. The assemblage structure was assessed in terms of three community parameters: richness, abundance and diversity (Shannon index). Their relationships with environmental variables were explored using correlation coefficients. The assemblage composition was analysed by multivariate techniques. First, the sites were classified by means of TWINSPAN. The presence of each species in the different TWINSPAN groups was used to assess their habitat preferences. Second, the sites and species were ordinated by Detrended Correspondence Analysis (DCA) using the CANOCO statistical package. Richness was significantly correlated with water permanence, conductivity and aquatic macrophyte cover. The first DCA axis was significantly correlated with water permanence and conductivity, but not with any of the other parameters. Conductivity was significantly inter-correlated with permanence. Therefore, water permanence and aquatic vegetation cover seem to be the main factors influencing richness, but only water permanence appears to determine species composition.
\end{abstract}

\section{INTRODUCTION}

Within the lentic environments of the Iberian Peninsula, and the Mediterranean basin in general, the temporary fresh or slightly mineralised waterbodies are of special interest because of their high biological diversity. In addition, they provide refuges for aquatic organisms in areas dominated by cereal farming with very few natural waterways. These fragile ecosystems are under threat from human pressure (draining, waste pollution) and climat conditions that have resulted in acute drought in recent years. These habitats can be safeguarded by developing preservation policies based on a comprehensive understanding of their genesis, physico-chemical characteristics, biological communities and function.

Water beetles and mosquitoes are the dominant insects in temporary environments (Collinson et al., 1995; Batzer \& Wissinger, 1996). Aquatic Coleoptera are abundant in many types of freshwater habitats, and there are over 600 species in the Iberian Peninsula (Ribera, 2000). In spite of the fact that most of the adults can fly, a detailed study of their autecology reveals species with special ecological requirements, which are useful bioindicators of particular aquatic environments (Castella et al., 1984; Flechtner, 1986; Davis et al., 1987; Eyre \& Foster, 1989; Foster et al., 1990, 1992; Ribera \& Foster, 1992; Eyre et al., 1992, 1993; Collinson et al., 1995; Moreno et al., 1997). Water beetles are considered by Eyre \& Foster (1989) as the most likely group to be of use in assessing environmental quality and change in standing water. They are good indicators of succession in aquatic environments of recent origin, both in Central Europe (Hebauer, 1988) and Spain (Valladares et al., 1994). Foster (1987) also gives reasons why aquatic Coleoptera are suitable for assessing the conservation status of sites.

The aim of this study is to determine the effect of environmental variables on the composition and structure of assemblages of aquatic Coleoptera in shallow inland lakes, with different degrees of permanence. This is important for the conservation of these lakes.

\section{MATERIAL AND METHODS}

\section{Study area}

A group of 12 shallow lakes situated on the edges of the Canal de Castilla in the centre and south of Palencia province, in the northern Iberian Meseta, were chosen for this study (Fig. 1). The Canal de Castilla is an artificial watercourse, $207 \mathrm{~km}$ long, running through the extensive steppe region of Tierra de Campos (Palencia and Valladolid provinces). It was built between 1753 and 1849 and was originally used for transporting goods, especially cereals, produced in the area. Today it is used for irrigation and supplying water to local towns.

The waterbodies associated with the Canal de Castilla are shallow lakes formed by drainage from the canal, rainwater, irrigation ditches and small streams which accumulate in depressions in the land, that are impermeable because of their marl and clay substrates. This, together with the harsh climate in the area - long winters and short hot summers $\left(12^{\circ} \mathrm{C}\right.$ mean annual tem- 


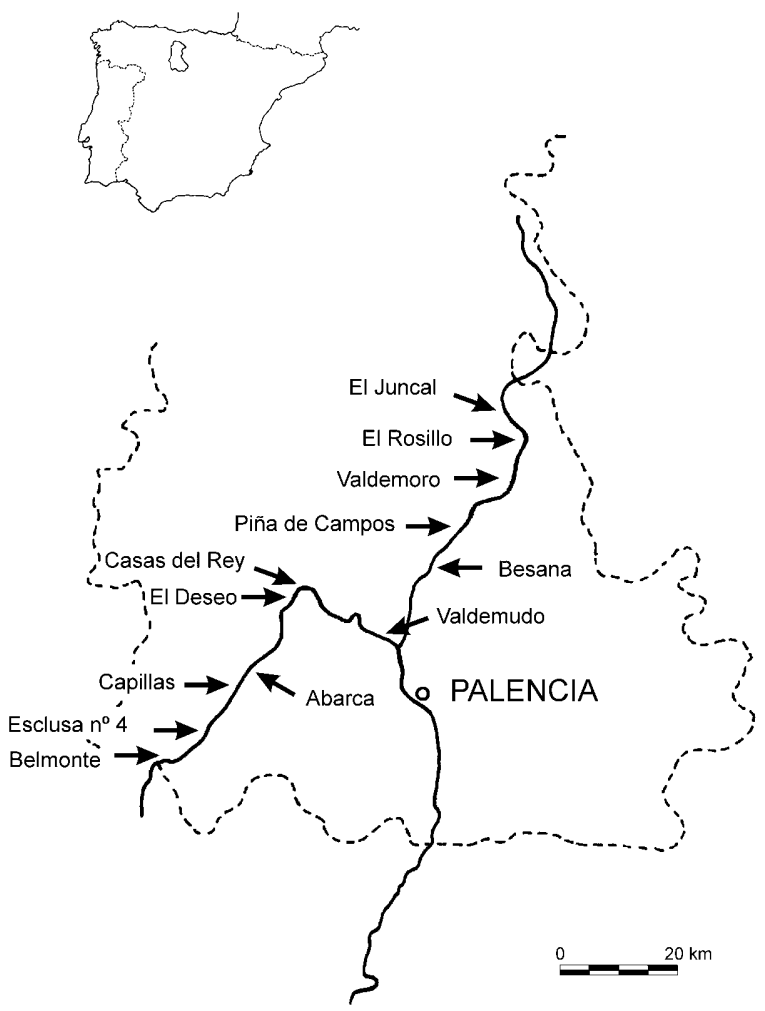

Fig. 1. Map of the study area showing the sampling sites.

perature) and very low annual rainfall (350 mm mean) determine the temporary nature of many of the shallow lakes. The altitudes of the sampling stations ranged from 750 to 800 $\mathrm{m}$. Some of the main environmental characteristics of the sampling sites are given in Table 1.

Vegetation, either emergent, aquatic or both, is abundant and sometimes occupies the entire surface of a shallow lake. The dominant vegetation is formed by emergent macrophytes such as Phragmites australis, Typha domingensis, Typha latifolia, Scirpus lacustris, Scirpus maritimus, Sparganium erectum or Juncus spp. and aquatic species including Drepanocladus aduncus (a bryophyte), Chara spp. (a charophyte), Polygonum amphibium, Potamogeton spp., Ranunculus spp. or Hippuris vulgaris.

\section{Sampling}

Aquatic Coleoptera were collected from 12 shallow lakes throughout a year (spring, summer and autumn 1998 and winter 1999) using a $250 \mu \mathrm{m}$ mesh $\mathrm{D}$-framed pond net. The captures were made close to the shore by sweeping three $4 \mathrm{~m}$ strips, paying attention to particular microhabitats. Two $10 \mathrm{~m}$ transects from the shore towards the middle were also sampled at each lake. A fine mesh strainer was used to collect the specimens floating on the surface after sweeping the bottom with the net. This semiquantitative method (area sampled and time spent sampling were similar at each site) allows structural parameters of the assemblage of aquatic Coleoptera at each site to be compared.

\section{Environmental variables}

The following environmental variables were recorded in situ at the same time as the Coleoptera were sampled: water temperature, $\mathrm{pH}$, conductivity and dissolved oxygen concentration. The water temperature was measured at different times during the day and occasionally on different days, and was therefore not used in the analysis. Along with the physical and chemical variables, the following environmental parameters were considered: area, perimeter, maximum depth and vegetation. The following categories were established for water permanence, depending on the number of months per year water was present in the lakes based on observations made over the last six years: ephemeral (1-2 months), very temporary (> 2-6 months), temporary ( $>6-9$ months), semipermanent $(>9-12$ months) and permanent (always contained water).

The following types of vegetation were considered: emergent macrophytes, aquatic macrophytes other than mosses, bryophytes and filamentous algae. Each type was assigned a value between 0 (absence) and 5 according to the degree of cover.

\section{Data processing}

The parameters used to assess the structure of the assemblage were species richness, abundance and diversity, calculated using the Shannon index $\left(\mathrm{H}^{\prime}\right)$.

TABLE 1. List of sampling sites and values of the environmental variables measured. Temperature, $\mathrm{pH}$, conductivity and oxygen concentration are the average of four samples. Sites are ordered according to the TWINSPAN group ("TWN group" column) to which they belong. The variable "aquatic macrophytes" refers to macrophytes other than mosses.

\begin{tabular}{|c|c|c|c|c|c|c|c|c|c|c|c|c|c|}
\hline & $\begin{array}{l}\text { TWN } \\
\text { group }\end{array}$ & $\begin{array}{l}\text { temp. } \\
\left({ }^{\circ} \mathrm{C}\right)\end{array}$ & $\mathrm{pH}$ & $\begin{array}{l}\text { conduct. } \\
(\mu \mathrm{S} / \mathrm{cm})\end{array}$ & $\begin{array}{c}\text { oxygen } \\
(\mathrm{mg} / \mathrm{l})\end{array}$ & $\begin{array}{c}\text { area } \\
\text { (hect.) }\end{array}$ & $\begin{array}{l}\text { perimeter } \\
\text { (m) }\end{array}$ & $\begin{array}{l}\text { depth } \\
(\mathrm{cm})\end{array}$ & perman. & $\begin{array}{c}\text { emer- } \\
\text { gent } \\
\text { macroph. }\end{array}$ & $\begin{array}{c}\text { aquatic } \\
\text { mac- } \\
\text { roph. }\end{array}$ & mosses & algae \\
\hline Besana & 1 & 13.13 & 8.14 & 608 & 6.9 & 4.70 & 990 & 180 & 5 & 2 & 5 & 1 & 0 \\
\hline $\begin{array}{l}\text { Casas del } \\
\text { Rey }\end{array}$ & 1 & 13.88 & 7.93 & 841 & 4.2 & 0.52 & 280 & 200 & 3 & 1 & 4 & 0 & 0 \\
\hline El Deseo & 1 & 12.53 & 7.63 & 800 & 5.0 & 2.65 & 1102 & 120 & 4 & 3 & 4 & 3 & 0 \\
\hline Belmonte & 1 & 11.38 & 7.76 & 466 & 6.4 & 2.22 & 1393 & 150 & 5 & 3 & 4 & 0 & 2 \\
\hline El Juncal & 2 & 9.38 & 7.91 & 665 & 6.0 & 0.76 & 367 & 120 & 3 & 4 & 3 & 0 & 0 \\
\hline El Rosillo & 2 & 9.00 & 7.59 & 1396 & 3.0 & 0.47 & 317 & 80 & 3 & 2 & 2 & 0 & 0 \\
\hline Valdemoro & 2 & 8.85 & 7.43 & 1333 & 3.0 & 8.34 & 2022 & 100 & 3 & 5 & 0 & 0 & 0 \\
\hline Valdemudo & 2 & 9.70 & 7.39 & 783 & 2.6 & 29.35 & 3454 & 250 & 5 & 5 & 1 & 0 & 0 \\
\hline $\begin{array}{l}\text { Piña de } \\
\text { Campos }\end{array}$ & 3 & 8.45 & 7.30 & 1107 & 3.3 & 1.25 & 654 & 30 & 2 & 5 & 0 & 0 & 0 \\
\hline Abarca & 3 & 8.45 & 7.28 & 721 & 3.1 & 2.05 & 1044 & 30 & 2 & 5 & 0 & 3 & 0 \\
\hline Capillas & 3 & 10.77 & 7.92 & 948 & 4.2 & 0.74 & 579 & 50 & 3 & 2 & 4 & 3 & 0 \\
\hline Esclusa $n^{\circ} 4$ & 4 & 8.50 & 8.00 & 1980 & 8.4 & 0.33 & 289 & 30 & 1 & 4 & 0 & 5 & 0 \\
\hline
\end{tabular}




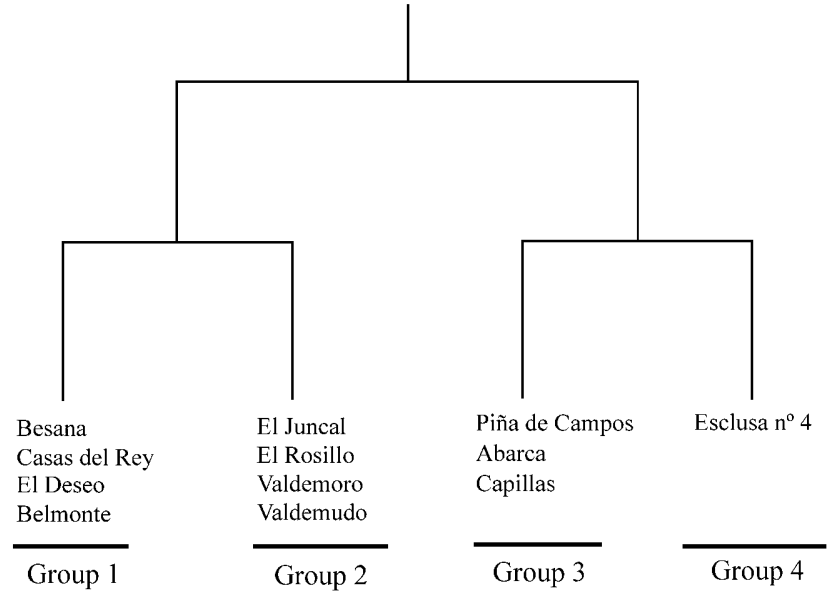

Fig. 2. Dendrogram of TWINSPAN end-groups for sites.

All the statistical analyses were carried out on global abundances: that is, total number of individuals collected at a site over the sampling period. The TWINSPAN programme was used to classify the localities. The cut-off levels for the pseudospecies were fixed at $0,3,10$ and 50 .

Sites and species were ordinated by DCA (Detrended Correspondence Analysis) using the canoco statistical package for Windows, version 4.02. The Kolmogorov-Smirnov test was used to verify that the DCA scores, the assemblage parameters and the variables, with the exception of "bryophytes" and "algae", were normally distributed. A correlation analysis between the site scores and the environmental variables was used to aid the interpretation of the DCA axes. The Pearson product-moment correlation coefficient was used for variables with normal distributions and the Spearman's rank correlation coefficient for the remaining two. The correlations between assemblage parameters and variables were made in the same way.

\section{RESULTS}

\section{Environmental variables}

Table 1 summarizes some of the characteristics of the shallow lakes and the average values of the variables measured during the study. The most outstanding features are the differences in area and degree of water permanence. A wide range of macrophyte cover (both emergent and aquatic other than mosses) is also evident, varying from 0 (absence) in some of the sites to 5 (almost completely covered).

\section{Assemblage composition}

Ninety two species of aquatic Coleoptera were identified among the 3,551 adults captured (Table 2). Of these, 44 belong to the Hydradephaga (Gyrinidae, Haliplidae, Noteridae, Hygrobiidae and Dytiscidae) and 48 to the Polyphaga (Hydrochidae, Helophoridae, Hydrophilidae, Hydraenidae, Dryopidae, Elmidae and Heteroceridae). Most of them have a Palaearctic distribution. Only two species endemic to Iberia were collected: Graptodytes castilianus, restricted to the northern Iberian Meseta, Iberian Cordillera and the Ebro depression, and Helophorus seidlitzii, which is widely distributed throughout the Peninsula (Ribera et al., 1998). Whilst $H$. seidlitzii was common in the shallow lakes, only $4 G$. castilianus speci- mens were captured. Ochthebius minimus, Limnebius furcatus, Helophorus brevipalpis, Berosus affinis, Enochrus nigritus, Noterus laevis and Graptodytes bilineatus were the most abundant species.

\section{Ecological parameters of the community}

Table 3 gives the global values recorded during the study for the structural parameters of the community. Richness for each site ranged from 22 (Esclusa $n^{\circ} 4$ ) to 43 (Belmonte), though most of them had more than 30 species. Abundance values varied between 108 specimens captured in Valdemoro and 702 in Deseo, while diversity values ranged between 2.62 (Esclusa $n^{\circ} 4$ ) and 4.43 (Abarca). There were more Coleoptera in spring (74 species, 1,406 specimens) and winter (72 species, 1,049 specimens). Abundance and richness decreased substantially in summer (488 specimens belonging to 42 species) and autumn (608 specimens from 47 species), partly because some of the lakes dried out in these seasons (4 during summer and 3 in autumn).

Richness was positively correlated with permanence ( $\mathrm{r}$ $=0.737, \mathrm{P}=0.006)$ and aquatic macrophyte cover $(\mathrm{r}=$ $0.716, \mathrm{P}=0.009$ ) and negatively correlated with conductivity $(\mathrm{r}=-0.67, \mathrm{P}=0.017)$. Diversity showed a negative correlation with conductivity $(\mathrm{r}=-0.753, \mathrm{P}=0.005)$. No significant correlations were detected between abundance and any of the variables.

\section{Classification and ordination}

TWINSPAN classified the sites into four groups (Fig. 2 ). Table 1 shows the values of the variables obtained at each locality. Variables that apparently discriminate the TWINSPAN groups are water permanence, conductivity and to a lesser extent, depth. However, sites are not clearly separated by any variable, with the exception of Esclusa $n^{\circ} 4$. Group 1 includes all the permanent (permanence value $=5$ ) and semipermanent (permanence value = 4) lakes except Valdemudo; they are all very deep. Group 2 is formed by most of the localities with intermediate persistence and that are comparatively deep. The third group includes two very temporary shallow lakes (permanence $=2$ ), and Capillas (permanence $=3$ ). Finally, the fourth group is formed exclusively by Esclusa $\mathrm{n}^{\mathrm{o}} 4$, the most ephemeral lake. The lakes in the last two groups are shallow.

Table 2 shows the percentage of localities within each TWINSPAN group at which each species was collected. Most species were widely distributed within the study area and are indifferent to the characteristics of the lakes, though they were often absent from ephemeral ponds (group 4). One group of species including mainly Ochthebius viridis 2, Hydrophilus pistaceus, Noterus clavicornis, Hygrobia hermanni, Bidessus goudoti and Cybister lateralimarginalis was associated with the more permanent shallow lakes (TWINSPAN group 1). In contrast, only a few species appear to be associated with very temporary or ephemeral waterbodies: Hydraena rugosa, Helophorus grandis and Haliplus variegatus.

The eigenvalues of the first four DCA axes were 0.687, $0.402,0.125$ and 0.024 , and the cumulative percentage of 


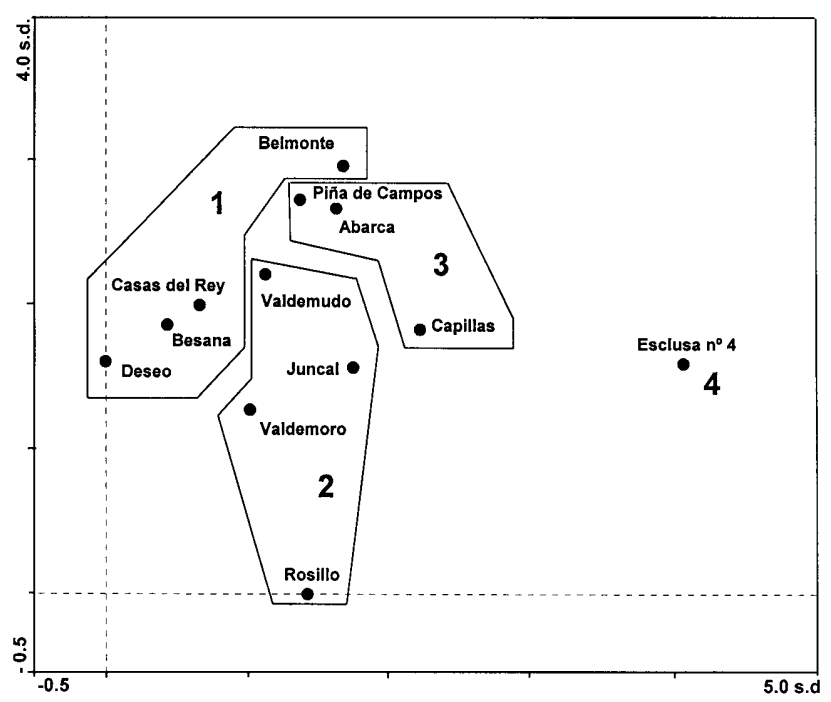

Fig. 3. Plot of the site scores for axes 1 and 2 of the DCA. Also shown are the TWINSPAN groups.

variance corresponding to the species data $24.7,39.2$, 43.7 and 44.6. Figs 3 and 4 show the ordination plots for sites and for species on axes 1 and 2. The TWINSPAN groups are also shown in Fig. 3. Group 4 is clearly separated from the others at the positive end of the first ordi- nation axis. Group 1 is separated at the opposite end, though less obviously so, while groups 2 and 3 overlap on the first axis. The first axis has a long gradient (4.07 standard deviation units), but only Esclusa $n^{\circ} 4$ is significantly separated from the other localities. Generally speaking, localities differing by 4 s.d. are not expected to have any species in common (Ter Braak, 1995), so it would be reasonable to expect different assemblages of species at the extremes of the gradient represented by axis 1. This points to the existence of an important faunistic turnover along the first ordination axis. This axis is positively correlated with conductivity $(\mathrm{r}=0.621, \mathrm{P}=0.031)$ and negatively correlated with permanence $(\mathrm{r}=-0.617, \mathrm{P}$ $=0.032$ ). There were no significant correlations with the other variables. We must therefore assume that this axis represents a water-permanence gradient: most temporary waterbodies are located at the right end of axis 1 , and the permanent and semipermanent ones at the left end of this axis. The length of the gradient of the second axis is 2.97 s.d. No significant correlations were found between the scores corresponding to this axis and any of the environmental variables. According to the ordination analysis, the following species were particularly abundant in the ephemeral ponds (positive end of axis 1): Hydraena rugosa, Berosus signaticollis, Dryops algiricus, Dryops similaris, Haliplus variegatus, Graptodytes bilineatus and

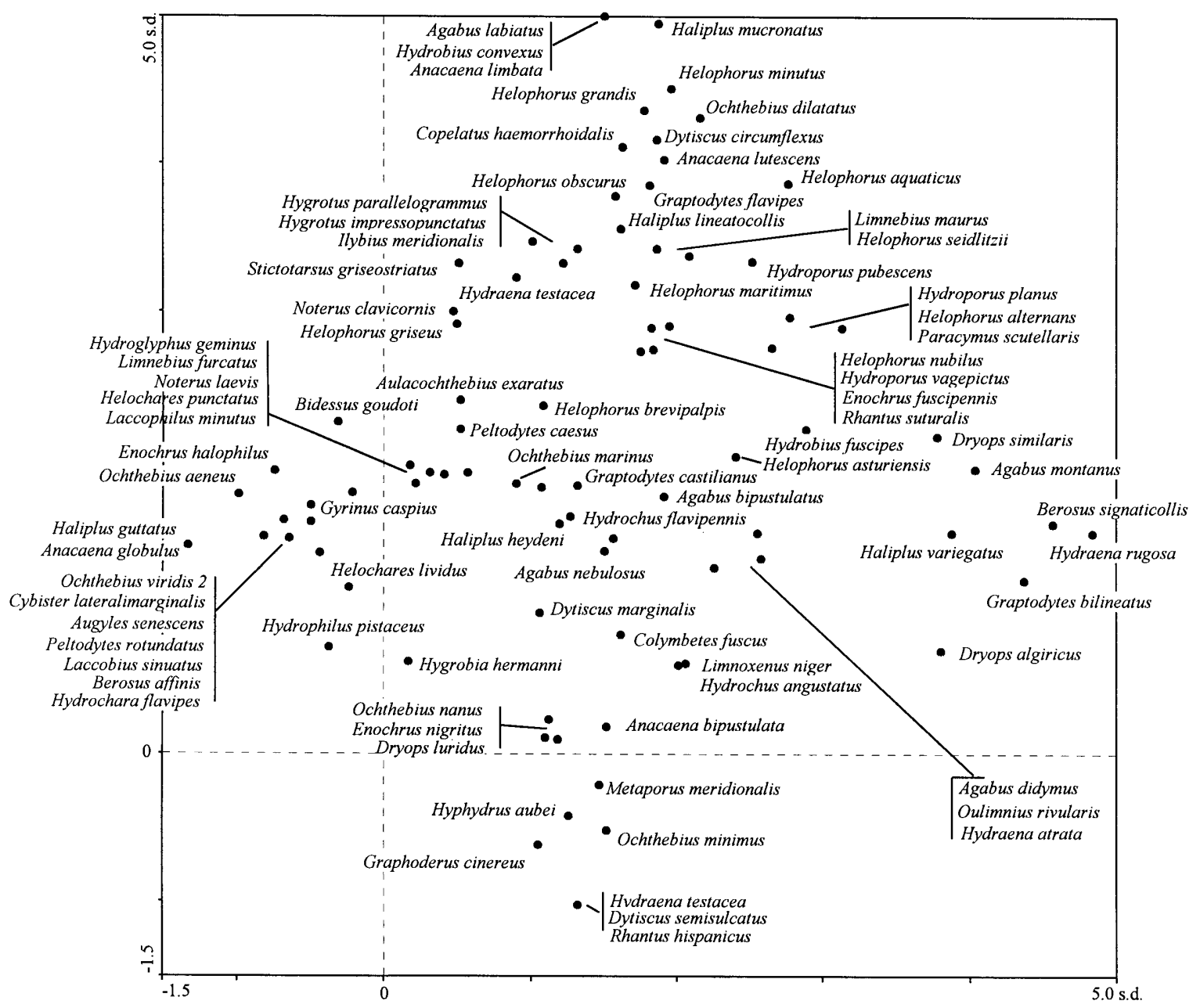

Fig. 4. Plot of the species scores for axes 1 and 2 of the DCA. 
GYrINIDAE

Gyrinus (Gyrimus) caspius Ménétries, 1832

Gyrinus (Gyrimus) distinctus Aubé, 1836

Halritida

Peltodytes (Peltodytes) caesus (Duftschmid, 1805)

Peltodytes (Peltodytes) rotundatus (Aubé, 1836)

Haliphus (Neohaliplus) lineatocollis (Marshan, 1802)

Haliplus (Haliplus) heydeni Wehncke, 1875

Haliplus (Liaphlus) guttatus Aubé, 1836

Haliphus (Liaphlus) mucronatus Stephens, 1828

Haliplus (Liaphlus) variegatus Sturm, 1834

Noteridae

Noterus clavicornis (De Geer, 1774)

Noterurs laevis Sturm, 1834

HYGRoBIIDAE

Hygrobia hermanni (Fabricius, 1775)

DyTISCIDAE

Bidessus goudoti (Castelnau, 1834)

Hydroglyphus geminus (Fabricius, 1792)

Hygrotus (Hygrotus) inaequalis (Fabricius, 1777)

Hygrotus (Coelambus) impressopunctatus (Schaller, 1783)

Hygrotus (Coelambus) parallelogrammus (Ahrens, 1812)

Hyphydrus (Hyphydrus) aubei Ganglbauer, 1892

Hydroporus (Hydroporus) analis Aubé, 1836

Hydroporus (Hydroporus) planus (Fabricius, 1781)

Hydroporus (Hydroporus) pubescens (Gyllenhal, 1808)

Hydroporus (Hydroporus) tessellatus Drapiez, 1819

Hydroporus (Hydroporus) vagepictus Fairmaire \& Laboulbène, 1854

Graptodytes bilineatus (Sturm, 1835)

Graptodytes castilianus Fery, 1995

Graptodytes flavipes (Olivier, 1795)

Metaporus meridionalis (Aubé, 1838)

Stictotarsus griseostriatus gr.

Copelatus haemorrhoidalis (Fabricius, 1787)

Agabus labiatus (Brahm, 1790)

Agabus bipustulatus (Linnaeus, 1767)

Agabus didymus (Olivier, 1795)

Agabus nebulosus (Forster, 1771)

Ilybius meridionalis (Aubé, 1836)

Ilybius montanus (Stephens, 1828)

Rhantus (Rhantus) hispanicus Sharp, 1880-82

Rhantus (Rhantus) suturalis (McLeay, 1825)

Colymbetes fuscus (Linnaeus, 1758)

Laccophilus minutus (Linnaeus, 1758)

Graphoderus cinereus (Linnaeus, 1758)

100

100

100

Dytiscus (Macrodytes) circumflexus Fabricius, 1801

Dytiscus (Macrodytes) marginalis Linnaeus, 1758

Dytiscus (Macrodytes) semisulcatus Müller, 1776

Cybister (Cybister) lateralimarginalis (De Geer, 1774) 


\begin{tabular}{|c|c|c|c|c|}
\hline & Group 1 & Group 2 & Group 3 & Group 4 \\
\hline Hydrochus flavipennis Küster, 1852 & 25 & 25 & & \\
\hline \multicolumn{5}{|l|}{ HELOPHORIDAE } \\
\hline Helophorus (Empleurus) nubilus Fabricius, 1776 & & 25 & 33 & \\
\hline Helophorus (Trichelophorus) alternans Gené, 1836 & 50 & 50 & 100 & 100 \\
\hline Helophorus (Helophorus) aquaticus (Linnaeus, 1758) & 25 & & 33 & 100 \\
\hline Helophorus (Helophorus) grandis Illiger, 1798 & & & 66 & \\
\hline Helophorus (Helophorus) maritimus Rey, 1885 & 75 & 75 & 66 & 100 \\
\hline Helophorus (Atracthelophorus) brevipalpis Bedel, 1881 & 100 & 75 & 100 & 100 \\
\hline Helophorus (Rhopalhelophorus) asturiensis Kuwert, 1885 & 50 & & 66 & 100 \\
\hline Helophorus (Rhopalhelophorus) griseus Herbst, 1793 & 75 & 50 & 100 & \\
\hline Helophorus (Rhopalhelophorus) minutus Fabricius, 1775 & & & 66 & \\
\hline Helophorus (Rhopalhelophorus) obscurus Mulsant, 1844 & & 50 & & \\
\hline Helophorus (Rhopalhelophorus) seidlitzii Kuwert, 1885 & 25 & 50 & 100 & 100 \\
\hline \multicolumn{5}{|l|}{ HYDROPHILIDAE } \\
\hline Berosus (Berosus) affinis Brullé, 1835 & 25 & 25 & 33 & \\
\hline Berosus (Berosus) signaticollis (Charpentier, 1825) & 75 & 25 & 66 & 100 \\
\hline Paracymus scutellaris (Rosenhauer, 1856) & 25 & 25 & 100 & 100 \\
\hline Anacaena bipustulata (Marsham, 1802) & 25 & 50 & 33 & \\
\hline Anacaena globulus (Paykull, 1798) & 25 & & & \\
\hline Anacaena limbata (Fabricius, 1792) & & & 33 & \\
\hline Anacaena lutescens (Stephens, 1829) & & 25 & 66 & \\
\hline Laccobius (Dimorpholaccobius) sinuatus Motschulsky, 1849 & 25 & & & \\
\hline Helochares (Helochares) lividus (Forster, 1771) & 100 & 50 & 33 & \\
\hline Helochares (Helochares) punctatus Sharp, 1869 & 75 & 100 & & \\
\hline Enochrus (Methydrus) nigritus (Sharp, 1872) & 50 & 100 & 66 & \\
\hline Enochrus (Lumetus) fuscipennis (C.G. Thomson, 1884) & 50 & & 33 & \\
\hline Enochrus (Lumetus) halophilus (Bedel, 1878) & 25 & 25 & & \\
\hline Hydrobius convexus Brullé, 1835 & & & 33 & \\
\hline Hydrobius fuscipes (Linnaeus, 1758) & 75 & 75 & 100 & 100 \\
\hline Limnoxemus niger (Zschach, 1788) & 50 & 75 & 66 & \\
\hline Hydrochara flavipes (Steven, 1808) & 25 & 25 & 33 & \\
\hline Hydrophilus pistaceus (Castelnau, 1840) & 75 & 25 & & \\
\hline \multicolumn{5}{|l|}{ HYDRAENIDAE } \\
\hline Hydraena (Phothydraena) atrata Desbrochers des Loges, 1891 & 25 & 50 & 33 & \\
\hline Hvdraena (Phothvdraena) testacea Curtis, 1830 & & 25 & & \\
\hline Hydraena (Hydraena) rugosa Mulsant, 1844 & & & & 100 \\
\hline Aulacochthebius exaratus (Mulsant, 1844) & 75 & 50 & & \\
\hline Ochthebius (Asiobates) aeneus Stephens, 1835 & 50 & & & \\
\hline Ochthebius (Asiobates) dilatatus Stephens, 1829 & 25 & 50 & 100 & 100 \\
\hline Ochthebius (Asiobates) minimus (Fabricius, 1792) & 100 & 75 & 66 & 100 \\
\hline Ochthebius (Ochthebius) marinus (Paykull, 1798) & 100 & & & 100 \\
\hline Ochthebius (Ochthebius) nanus Stephens, 1829 & & 50 & & \\
\hline Ochthebius (Ochthebius) viridis 2 sensu Jäch 1991 & 75 & 25 & & \\
\hline Limnebius furcatus Baudi, 1872 & 100 & 100 & 100 & \\
\hline Limnebius maurus Balfour-Browne, 1978 & & 50 & 33 & \\
\hline \multicolumn{5}{|l|}{ DRYOPIDAE } \\
\hline Dryops algiricus (Lucas, 1849) & & 25 & 33 & 100 \\
\hline Dryops luridus (Erichson, 1847) & & 25 & & \\
\hline Dryops similaris Bolow, 1936 & 50 & & 66 & 100 \\
\hline \multicolumn{5}{|l|}{ ElMmDAE } \\
\hline Oulimnius rivularis (Rosenhauer, 1856 ) & & 25 & 33 & \\
\hline \multicolumn{5}{|l|}{ HETEROCERIDAE } \\
\hline Augyles senescens (Kiesenwetter, 1865) & 25 & & & \\
\hline
\end{tabular}


TABLE 3. Global values of the assemblage parameters at each lake. Diversity was measured by the Shannon index.

\begin{tabular}{lccc}
\hline & Richness & Abundance & Diversity \\
\hline El Juncal & 26 & 175 & 3.91 \\
El Rosillo & 32 & 430 & 2.95 \\
Valdemoro & 32 & 108 & 4.30 \\
Piña de Campos & 27 & 138 & 3.43 \\
Besana & 39 & 410 & 3.91 \\
Valdemudo & 33 & 243 & 4.20 \\
Casas del Rey & 36 & 338 & 3.75 \\
El Deseo & 39 & 703 & 3.71 \\
Abarca & 33 & 165 & 4.43 \\
Capillas & 39 & 205 & 4.22 \\
Esclusa $\mathrm{n}^{\circ} 4$ & 22 & 367 & 2.62 \\
Belmonte & 43 & 274 & 4.38 \\
\hline
\end{tabular}

Agabus montanus. At the opposite extreme is a larger group of species linked to permanent or semipermanent ponds, including Anacaena globulus, Ochthebius aeneus, Ochthebius viridis 2, Cybister lateralimarginalis, Berosus affinis, Enochrus halophilus, Gyrinus caspicus, Gyrinus distinctus, Laccophilus sinuatus, Hydrochara flavipes, Bidessus goudoti, Helochares lividus and Hydrophilus pistaceus.

\section{DISCUSSION}

The richness of aquatic Coleoptera recorded in this study is high compared to that previously recorded for shallow lakes in the northern Iberian Meseta and other Spanish wetlands. For example, only 50 species were collected in the nearby Laguna de la Nava (Valladares et al., $1994)$ in spite of its much larger area. Régil \& Garrido (1993) recorded 31 Hydradephaga species in the Villafáfila shallow lakes (NW Iberian Meseta). Data from studies carried out over large areas of the Iberian Peninsula and southwestern France, each including a large number of stagnant waterbodies, also corroborate the particularly high values for species richness in the Canal de Castilla. For example, 37 species were recorded in the Ebro Delta by Ribera et al. (1996), 45 in the Ramblas de Murcia (southeastern Spain) by Moreno et al. (1997), 97, excluding Chrysomelidae and Curculionidae, in the Marais de La Perge (southwestern France) by Bameul (1994), 102 in the Estanys de Capmany (Pyrenees) by Ribera \& Aguilera (1996) and 102 in stagnant water in the Albacete Province (southeastern Spain) by Millán et al. (2001). Similarly, 39 Polyphaga species have been recorded so far in the Doñana National Park (Garrido et al., 1996). Bameul (1994) estimated that a wetland supporting from 40 to 50 species of water beetles is a "good" station. Species richness is one of the most important parameters used to assess the conservation value of an environment (Duigan et al., 1998). Therefore, the shallow lakes associated with the Canal de Castilla should be considered for conservation.

Seasonal variation in richness was similar to that observed in La Nava (Valladares et al., 1994), where spe- cies number was lowest in summer, with peaks in autumn and early spring which is when flooding occurs. The species that have adapted to such temporary environments complete their life cycles (adults and larvae) during the rainy seasons and so the species richness increases. This is very common in Hydradephaga (Larson, 1985; Ribera et al., 1994) which adapt their biological cycles to temporary conditions and have a short larval and long adult life.

Diversity values are also high in comparison with $\mathrm{La}$ Nava (H'=3-3.5) (Valladares et al., 1994) and the permanent marshes of the lower Guadalquivir (Montes et al., 1982). The diversity of Hydradephaga inhabiting the Pyrenees was also lower (2.5-3) (Ribera et al., 1994).

The degree of permanence is undoubtedly an important parameter determining the composition of the macroinvertebrate community in lakes (Williams, 1997). Eyre et al. (1992) and Foster et al. (1992) reached the same conclusions for Coleoptera and Collinson et al. (1995) for the whole macroinvertebrate assemblage using TWINSPAN and DCA. The latter authors also pointed out that temporary ponds contain fewer species. Moreno et al. (1997) considered salinity and vegetation type as the main variables in determining the distribution of Coleoptera and Heteroptera in "ramblas" in the southeastern Iberian Penninsula, but they also found water permanence to be an important factor. They also concluded that the most permanent waterbodies are the richest in species.

The analyses carried out in the present study show that water permanence is the main variable influencing water beetle fauna. This influence is evident both in terms of species number (a significant correlation between this parameter and species richness was found) and species composition, as suggested by the multivariate analysis. Therefore, the results of this study point to the possibility that habitats with low water permanence are inhabited by poor assemblages with a more or less characteristic species composition. The fact that conductivity was also related to the Coleoptera fauna is a result of the relationship between this variable and permanence: the most ephemeral water bodies have high evaporation rates and accumulate more solutes.

High aquatic macrophyte cover also seems to favour the existence of a rich beetle assemblage, but it does not appear to have a significant influence on the specific composition of the assemblage or, at least, the multivariate analysis failed to detect it. This result is contrary to the opinion expressed by Eyre et al. (1992), who observed a relationship between the second DCA axis and vegetation type. In addition, Moreno et al. (1997) considered that vegetation type was one of the factors most closely related to the first ordination axis. In both cases, the differences in vegetative cover between the waterbodies were greater than in this study ranging from ponds densely covered with vegetation to those that were either "uncovered" or were covered with epipelon only. In the present study, vegetation (emergent, aquatic or both) was abundant in all the lakes. In a similar situation, Palmer (1981) found that a greater richness of macrophytes 
implies more species of Coleoptera, but gave no information about the specific composition of the assemblage.

We can deduce that lake area did not influence the beetle fauna, a conclusion also reached by Duigan et al. (1998).

The biggest difference in the beetle fauna was between that in the very ephemeral shallow lake (Esclusa $n^{\circ} 4$ ), which had a characteristic fauna, and the permanent or temporary lakes. The faunistic homogeneity of the permanent and moderately temporary ponds may reflect their geographical proximity (approximately $105 \mathrm{kms}$ distance between the first and the last), their similar origin and vegetation, all of which favour faunistic uniformity.

It has often been claimed that water beetles are adapted to temporary environments (Collinson et al., 1995), but this is true only for some species (Bratton, 1990). The present study has also shown differences in the response of the species to this factor. Although there is some overlap, we can define a community characteristic of ephemeral waterbodies and another of semipermanent or permanent shallow lakes.

Hydraena rugosa, Berosus signaticollis, Dryops algiricus, Dryops similaris, Haliplus variegatus, Graptodytes bilineatus and Ilybius montanus belong to the former. Helophorus grandis, could also be included in this group. The adaptation of $H$. rugosa to temporary waters was mentioned by Valladares (1989), Garrido et al. (1996) and Sáinz-Cantero et al. (1997). Ribera et al. (1995b) found that the abundance of Graptodytes bilineatus was inversely related to depth of lakes in the Pyrenees, which suggests selection for temporary habitats. Helophorus grandis is also characteristic of small lakes (Angus, 1992) and temporary environments with a substrate covered with grass (Hansen, 1987). Of the two Berosus species collected in the study area, $B$. signaticollis is more capable of colonising temporary or recently-formed environments, even occupying small pools filled with rainwater in Holland (Cuppen \& Mannen, 1998). On the contrary, Berosus affinis is a eurytopic species, whose biological cycle is adapted to temporary and permanent habitats (Aouad, 1988).

The second group, typical of permanent or semipermanent habitats, is formed by Anacaena globulus, Ochthebius aeneus, Ochthebius viridis 2, Cybister lateralimarginalis, Berosus affinis, Enochrus halophilus, Gyrinus caspius, Gyrinus distinctus, Laccophilus sinuatus, Hydrochara flavipes, Bidessus goudoti, Helochares lividus and Hydrophilus pistaceus. Noterus clavicornis and Hygrobia hermanni also prefer these habitats, but are sometimes found in more temporary bodies of water. Berge Henegouwen (1986) indicated that Anacaena globulus occurs in permanent and semi-permanent habitats in Europe. Likewise, Hygrobia hermanni is also typical of permanent waterbodies (Biggs et al., 1994; Valladares et al., 1994) and usually avoids very shallow, small waterbodies (Ribera et al., 1995a; Cuppen, 2000). Large species such as Hydrophilus pistaceus, Hydrochara flavipes and Cybister lateralimarginalis are nearly always associated with areas containing a great volume of water
(Ribera et al., 1994). Noterus clavicornis is considered by Ribera et al. (1995a) to be a characteristic species of large, shallow lakes with abundant vegetation. Ochthebius aeneus and Ochthebius viridis are similar, and are both associated with banks with shallow brackish pool vegetation (Hansen, 1987). Adult Helochares lividus found in Western Europe show little capacity to colonise temporary habitats (Cuppen, 1986).

In conclusion, in terms of fauna of Coleoptera, it would appear that temporary shallow lakes are as equally interesting as permanent lakes when it comes to applying conservation programmes. The most ephemeral waterbodies are comparatively poor in species, but may support a characteristic beetle assemblage, with species that are absent (Hydraena rugosa) or very scarce (Berosus signaticollis, Dryops similaris, Graptodytes bilineatus) in more permanent lakes. The conversion of ephemeral waterbodies into permanent waterbodies (by inundation during periods of drought or increasing the depth by dredging) could eliminate the specialized species. Temporary shallow lakes often house rare species that are particularly adapted to this type of enviromment (Batzer \& Wissinger, 1996; Williams, 1997). This is the case with Hydraena rugosa, rare in its distribution area (Valladares \& Montes, 1991). The importance of temporary habitats in conservation programmes has been stressed by authors such as Neckles et al. (1990) and Biggs et al. (1994). The periodic drying out of shallow lakes does not necessarily have a dramatic effect on the macroinvertebrate asemblages. In contrast, it may be a mistake to focus the implementation of conservation measures only on large waterbodies, because they do not necessarily contain richer or characteristic assemblages.

ACKNOWLEDGEMENTS. Our thanks to I. Ribera, J.A. Díaz and A. Mascagni for their help in identifying some species and their comments. Many thanks to our colleagues in Palencia: J. Barrocal, A. Hernández, B. Herrero and J.J. Parra for their invaluable help during field work. N.F. Santiago promoted the study and contributed important data on environmental variables for the shallow lakes, especially vegetation. This research was financed by Project VA38/98, Junta de Castilla y León and the European Social Fund.

\section{REFERENCES}

Angus R.B. 1992: Insecta: Coleoptera: Hydrophilidae: Helophorinae.-Süsswasserfauna von Mitteleuropa, 20/10-2. G. Fischer, Stuttgart, 144 pp.

AouAD N. 1988: The biological cycle and polymorphism of Berosus affinis (Coleoptera: Hydrophilidae) in Marocco. Entomol. News 99: 105-110.

Bameul F. 1994: Les Coléoptères aquatiques des Marais de La Perge (Gironde), témoins de la fin des temps glaciaires en Aquitaine. Bull. Soc. Entomol. France 99: 301-321.

BATZER D.T. \& WISSINGER S.A. 1996: Ecology of insect communities in nontidal shallow lakes. Annu. Rev. Entomol. 41: $75-100$.

Berge Henegouwen van A. 1986: Revision of the European species of Anacaena Thomson (Coleoptera: Hydrophilidae). Entomol. Scan. 17: 393-407. 
Biggs J., Corfield A., Walker D., Whitfield M. \& Williams P. 1994: New approaches to the management of ponds. British Wildlife 5: 273-287.

Bratton J.H. 1990: Seasonal pools. An overlooked invertebrate habitat. British Wildlife 2: 22-29.

Castella E., Richardot-Coule M., Roux C. \& Richoux P. 1984: Macroinvertebrates as "describers" of morphological and hydrological types of aquatic ecosystems abandoned by Rhone River. Hydrobiologia 119: 219-225.

Coluinson N.H., Biggs J., Corfield A., Hodson M.J., Walker D., Whitfield M. \& Williams P.J. 1995: Temporary and permanent ponds: An assessment of the effects of drying out on the conservation value of aquatic macroinvertebrate communities. Biol. Conserv. 74: 125-133.

CUPPEN J.G.M. 1986: On the habitats, distribution and lifecycles of the Western European species of the genus Helochares Mulsant (Coleoptera: Hydrophilidae). Hydrobiologia 132: 169-183

CuPPEN J.G.M. 2000: Distribution, phenology, food and habitat of Hygrobia hermanni in the Netherlands (Coleoptera: Hygrobiidae). Entomol. Ber. Amst. 60: 53-60.

Cuppen J.G.M. \& Manen van B. 1998: Distribution and habitats of Berosus in The Netherlands (Coleoptera: Hydrophilidae). Entomol. Ber. Amst. 58: 213-223.

Davis J.A., Rolls S.W. \& Balla S.A. 1987: The role of the Odonata and aquatic Coleoptera as indicators of environmental quality in shallow lakes. In Majer J.D. (ed.): The Role of Invertebrates in Conservation and Biological Survey. Western Australian Department of Conservation and Land Management Report, Perth, WA, pp. 31-42.

Duigan C.A., Allott T.E.H., Monteith D.T., Patrick S.T., LANCAster J. \& Seda J.M. 1998: The ecology and conservation of Llyn Idwal and Llynd Cwellyn (Snowdonia National Park, North Wales, U.K.) - two lakes proposed as Special Areas of Conservation in Europe. Aquatic Conserv.: Mar. Freshw. Ecosyst. 8: 325-360.

Erre M.D. \& Foster G.N. 1989: A comparison of aquatic Heteroptera and Coleoptera communities as a basis for environmental and conservation assessments in static water sites. $J$. Appl. Entomol. 108: 355-362.

Eyre M.D., Carr R., McBlane R.P. \& Foster G.N. 1992: The effects of varying site-water duration on the distribution of water beetle assemblages, adults and larvae (Coleoptera: Haliplidae, Dytiscidae, Hydrophilidae). Arch. Hydrobiol. 124: 281-291.

Eyre M.D., Foster G.N. \& Young A.G. 1993: Relationships between water-beetle distributions and climatic variables: A possible index for monitoring global climatic change. Arch. Hydrobiol. 127: 437-450.

FleChtNer G. 1986: Association analysis of water-beetles communities (Coleoptera, Dytiscidae et Haliplidae). Entomologica Basiliensia 11: 297-308

FosteR G.N. 1987: The use of Coleoptera records in assessing the conservation status of shallow lakes. In Luff M.L. (ed.): The Use of Invertebrates in Site Assessment for Conservation. Proceedings of a Meeting of the Agricultural Environment Research Group, University of Newcastle upon Tyne, pp. $8-18$.

Foster G.N., Foster A.P., Eyre M.D. \& Bilton D.T. 1990: Classification of water beetles assemblages in arable fenland and ranking of sites in relation to conservation value. Freshw. Biol. 22: 343-354

Foster G.N., Nelson B.H., Bilton D.T., Lott D.A., Merrit R., WEYL R.S. \& EYRE M.D. 1992: A classification and evaluation of Irish water beetle assemblages. Aquatic Conserv.: Mar. Freshw. Ecosyst. 2: 185-208.
Garrido J., Sáinz-Cantero C.E. \& Díaz J.A. 1996: Fauna entomológica del Parque Nacional de Doñana (Huelva, España) I. (Coleoptera: Polyphaga). Nouv. Revue Entomol. (N.S.) 13: 57-71.

LARSON D.J. 1985: Structure in temperate predaceus diving beetle communities (Coleoptera: Dytiscidae). Holartic Ecol. 8: $18-32$.

Hansen M. 1987: The Hydrophiloidea (Coleoptera) of Fennoscandia and Denmark. Fauna Entomol. scand. 18. E.J. Brill/Scandinavian Science Press Ltd., Leiden-Copenhagen, $254 \mathrm{pp}$.

HEBAUER F. 1988: Gesichtspunkte der ökologischen Zuordnung aquatischer Insekten zu den Sukzessionsstufen der Gewässer. Ber. ANL 12: 229-239.

Millán A., Moreno J.L. \& Velasco J. 2001: Estudio faunístico y ecológico de los Coleópteros y Heterópteros acuáticos de las lagunas de Albacete (Alboraj, Los Patos, Ojos de Villaverde, Ontalafia y Pétrola). Sabuco, Revista de Estudios Albacetenses 1: 43-94.

Montes C., Ramírez L. \& Soler A.G. 1982: Variación estacional de las taxocenosis de Odonatos, Coleópteros y Heterópteros acuáticos en algunos ecosistemas del bajo Guadalquivir (SW España) durante un ciclo anual. Anales Univ. Murcia (Cienc.) 38: 21-100.

Moreno J.L., Millán A., Suárez M.L., Vidal-Abarca M.R. \& Velasco J. 1997: Aquatic Coleoptera and Heteroptera assemblages in waterbodies from ephemeral coastal streams ("ramblas") of south-eastern Spain. Arch. Hydrobiol. 141: 93-107.

Neckles H.A., Murkin H.R. \& COOPer J.A. 1990: Influences of seasonal flooding on macroinvertebrate abundance in shallow lake habitats. Freshw. Biol. 23: 311-322.

Palmer M. 1981: Relationship between species richness of macrophytes and insects in some water bodies in the Norfolk Breckland. Entomol. Month. Mag. 117: 35-46.

RÉGL J.A. \& GARRDO J. 1993: Fauna acuática de las Lagunas de Villafáfila (Zamora, España) (Coleoptera: Adephaga). Bull. Soc. Entomol. France 98: 371-380.

RIBERA I. 2000: Biogeography and conservation of Iberian water beetles. Biol. Conserv. 92: 131-150.

Ribera I. \& Agullera P. 1996: Els Estanys de Capmany: The missing Spanish Pingo (or Palsa) fens? Latissimus 7: 2-6.

Ribera I., \& Foster G.N. 1992: Uso de coleópteros acuáticos como indicadores biológicos (Coleoptera). Elytron 6: 61-75.

Ribera I., Bilton D.T., Aguilera P. \& Foster G.N. 1996: A north African-European transition fauna: water beetles (Coleoptera) from the Ebro Delta and other Mediterranean coastal wetlands in the Iberian Peninsula. Aquatic Conserv.: Mar. Freshw. Ecosyst. 6: 121-140.

Ribera I., Hernando C. \& Aguilera P. 1998: An annotated check-list of the Iberian water beetles (Coleoptera). Zapateri Revta. Aragon. Entomol. 8: 43-111.

Ribera I., Isart J. \& RÉGIL J.A. 1994: Coleópteros acuáticos de los Estanys de Capmany (Girona): Hydradephaga. Scientia Gerundensis 20: 17-34.

Ribera I., IsART J. \& Régil J.A. 1995a: Autoecología de algunas especies de Hydradephaga (Coleoptera) de los Pirineos. I. Gyrinidae, Haliplidae, Noteridae e Hygrobiidae. Zool. Baetica 6: 33-58.

Ribera I., IsARt J. \& Régil J.A. 1995b: Autoecología de algunas especies de Hydradephaga (Coleoptera) de los Pirineos. II. Dytiscidae. Zool. Baetica 6: 59-104.

Sáinz-Cantero C.E., Garrido J. \& Valladares L.F. 1997: Contribución al conocimiento del género Hydraena Kugelann, 1794 (Coleoptera: Hydraenidae) en la Península Ibérica e islas Baleares. Zool. Baetica 8: 213-219. 
Ter BraAk C.J.F. 1995: Ordination. In Jongman R.H.G., Ter Braak C.J.F. \& van Tongeren O.F.R. (eds): Data Analysis in Community and Landscape Ecology. Cambridge University Press, Cambridge, pp. 91-173.

Valladares L.F. 1989: Los Palpicomia acuáticos de la provincia de León. II. Hydraena Kugelann, 1794 y Limnebius Leach, 1815 (Coleoptera: Hydraenidae). Boln. Asoc. Esp. Entomol. 13: 313-330.

VAlladares L.F. \& Montes C. 1991: Lista Faunística y Bibliográfica de los Hydraenidae (Coleoptera) de la Península Ibérica e Islas Baleares. Listas de la Flora y Fauna de las aguas continentales de la Península Ibérica 10. Asociación Española de Limnologia, Madrid, 93 pp.

Valladares L.F., Garrido J. \& Herrero B. 1994. The annual cycle of the community of aquatic Coleoptera (Adephaga and Polyphaga) in a rehabilitated wetland pond: the Laguna de La Nava (Palencia, Spain). Annls Limnol. 30: 209-220.

WILLIAMS D.D. 1997: Temporary ponds and their invertebrate communities. Aquatic Conserv.: Mar. Freshw. Ecosyst. 7: 105-117.

Received June 14, 2001; revised August 6, 2001; accepted September 20, 2001 